\title{
SOYBEAN CULTIVARS YIELD IN ALTERNATIVE PLANT ARRANGEMENTS
}

\author{
Rodrigo Arroyo Garcia ${ }^{1}$, Guilherme Sutiér ${ }^{2}$ \\ ${ }^{1}$ Embrapa Agropecuária Oeste. E-mail: rodrigo.garcia@embrapa.br \\ ${ }^{2}$ Centro Universitário da Grande Dourados - Unigran. E-mail: guilherme_sutier@ hotmail.com
}

\section{ABSTRACT}

The objective of this work was to evaluate soybean cultivars cropped in different plant row spacing $(20 \mathrm{~cm}$, double rows with $20 \times 60 \mathrm{~cm}$, conventional with $45 \mathrm{~cm}$ and crossed rows with 45 cm) and plants population in the 2012/2013, 2013/2014 and 2014/2015 growing seasons in Dourados; and in the 2014/2015 growing season in Ponta Porã, Mato Grosso do Sul State, Brazil. Soybean grain yield was evaluated considering $13 \%$ of moisture. Plant architecture was measured through branches contribution in grain yield and number of reproductive branches. The effects of row spacing on the soybean grain yield were specifics. They are dependent of cultivars and rainfall conditions. Therefore, does not support changes on the conventional row spacing currently adopted. Soybean cultivars with indeterminate habit growth, even being more compacted, showed capacity of changing its architecture as affected by row spacing and plant population. Same behavior is well known in the literature, however, in cultivars with determinate growth.

Keywords: Crossed rows, double rows, Glycine max, indeterminate soybean

\section{PRODUTIVIDADE DE CULTIVARES DE SOJA EM ARRANJOS DE PLANTAS ALTERNATIVOS}

\section{RESUMO}

Objetivou-se avaliar cultivares de soja em diferentes espaçamentos $(20 \mathrm{~cm}$, fileiras duplas de 20x60 cm, convencional a $45 \mathrm{~cm}$ e cruzado a $45 \mathrm{~cm}$ ) e populações de plantas, nas safras 2012/2013, 2013/2014 e 2014/2015 em Dourados, Mato Grosso do Sul, Brasil, e 2014/2015 em Ponta Porã, Mato Grosso do Sul, Brasil. Foram avaliadas a produtividade de grãos, com teor de água corrigido para $13 \%$, e a arquitetura das plantas, pela contribuição dos ramos na produtividade e número de ramos reprodutivos. Os efeitos dos espaçamentos alternativos na produtividade de grãos de soja foram pontuais, além de serem dependentes da cultivar e condições de chuvas. 
Portanto, não sustentam alterações do espaçamento convencional adotado atualmente. As cultivares com tipo de crescimento indeterminado, apesar de mais compactas, continuam apresentando considerável plasticidade, alterando a arquitetura das plantas em função de mudanças no espaçamento e população de plantas. Esse mesmo comportamento já era conhecido na literatura, no entanto, nas cultivares com tipo de crescimento determinado.

Palavras-chave: Plantio cruzado, fileira dupla, Glycine max, soja indeterminada

\section{INTRODUCTION}

The introduction of soybean varieties with indeterminate growth habit has led to many changes in agricultural production systems including the cultivation of this oilseed crop. In general, these varieties tolerate early sowing, provides high yields, and grows to adequate height such that plant size is suitable for mechanized harvesting (TANAKA \& SHIRAIWA, 2009). The early maturity of indeterminate soybean has enabled growers to plant a second maize crop in several regions of Brazil. In case of the states of Mato Grosso do Sul and Paraná, for example, sowing is typically done in January/February, and during this period, the crop is exposed to abundant rainfall with minimal risk of frost damage, which may be common in autumn/winter in this region (FIETZ et al., 2013).

The genotypes with indeterminate growth offer some distinct advantages compared to the determinate cultivars. One of the most remarkable aspects is the ability of the soybean plant to continue vegetative growth even after initiation of flowering. Several soybean cultivars have the potential of tripling their size even after early flowering. This is a limiting factor in most determinate genotypes, especially in harvest forecasting. Moreover, these cultivars can be considered to be modern and unique due to their lower branching canopy. The main stem is responsible for a major portion the pod yield. Small leaflets in the upper one-third, in addition to a slope of leaflets and branches, are characteristic of cultivars with indeterminate growth. One of the major advantages of indeterminate soybeans over determinate varieties is the fact the indeterminate cultivars can recuperate after periods of dry weather. (TANAKA \& SHIRAIWA, 2009; PROCÓPIO et al., 2013).

In keeping with this notion, it is believed that due to the growth and architecture of these cultivars, modifications to soybean plants could result in yield increase. Some of the goals of modifying plants population and increasing density is to decrease the distance between rows, 
enabling rapid capture of at least $95 \%$ of sunlight, and to maximize the amount of light captured per unit of area and time (SHAW \& WEBER, 1967). With dense planting, it is possible to achieve productivity gains, where the performance of each plant is not compromised by the increase in individuals per unit area.

Changing the planting arrangement is a quick and relatively easy operation to increase production of soybean. The results of several studies with various planting arrangements and population densities for soybean have been reported (BULLOCK et al., 1998; MARTINS et al., 1999; PEIXOTO et al., 2000; PIRES et al., 2000; RAMBO et al, 2004, THOMAS et al., 1998). In general, due to the manipulability of the soybean plant and the characteristics of the cultivars used, the results are variable. In recent studies, results are also contrary to cross-sowing (PROCÓPIO et al, 2013; BALBINOT JUNIOR et al, 2015a; SILVA et al, 2015; SOUZA et al, 2016). In this context, the experiments conducted during the crop seasons 2012/2013, 2013/2014 and 2014/2015 in the Mato Grosso do Sul State aimed at evaluating the yield of soybean grains grown in different arrangements, with variations in spacing and plant populations.

\section{MATERIAL AND METHODS}

The experiments were conducted in the 2012/2013, 2013/2014, and 2014/2015 crop seasons in Dourados, Mato Grosso do Sul State, and, 2014/2015 in Ponta Porã, Mato Grosso do Sul State, Brazil, in experimental areas of Embrapa Agropecuária Oeste. In Dourados, the soil was classified as dystrophic red latosol with a heavy clay texture (EMBRAPA, 2006) and chemical analysis indicated the following: $\mathrm{pH}\left(\mathrm{CaCl}_{2}\right) 5.16 ; 45.2 \mathrm{mg} \mathrm{dm}^{-3} \mathrm{P}$ (Melich1); $28.9 \mathrm{~g} \mathrm{~kg}^{-1}$ organic matter; $5.43 \mathrm{cmol}_{\mathrm{c}} \mathrm{dm}^{-3} \mathrm{H}+\mathrm{Al} ; 0.98 \mathrm{cmol}_{\mathrm{c}} \mathrm{dm}^{-3} \mathrm{~K} ; 4.6 \mathrm{cmol}_{\mathrm{c}} \mathrm{dm}^{-3} \mathrm{Ca} ; 1.9 \mathrm{cmol}_{\mathrm{c}} \mathrm{dm}^{-3} \mathrm{Mg}$; total exchangeable bases (SB) of $7.48 \mathrm{cmolc} \mathrm{dm}^{-3}$; cation exchange capacity (CEC) of $12.91 \mathrm{cmol}_{\mathrm{c}} \mathrm{dm}^{-}$ 3; and base saturation (V) of 58\%. Geographic coordinates are latitude $22^{\circ} 13^{\prime} 16^{\prime \prime} \mathrm{S}$, longitude $54^{\circ}$ 48' 20"W and altitude of $430 \mathrm{~m}$. For Ponta Porã, the soil was classified as dystroferric red latosol of medium texture (EMBRAPA, 2006) and chemical analysis indicated the following: $\mathrm{pH}\left(\mathrm{CaCl}_{2}\right)$ 5.0; $25.0 \mathrm{mg} \mathrm{dm}^{-3} \mathrm{P}$ (Melich1); $28.0 \mathrm{~g} \mathrm{~kg}^{-1}$ organic matter; $3.0 \mathrm{cmol}_{\mathrm{c}} \mathrm{dm}^{-3} \mathrm{H}+\mathrm{Al} ; 0.33 \mathrm{cmol}_{\mathrm{c}} \mathrm{dm}^{-3}$ $\mathrm{K} ; 2.5 \mathrm{cmol}_{\mathrm{c}} \mathrm{dm}^{-3} \mathrm{Ca} ; 0.9 \mathrm{cmol}_{\mathrm{c}} \mathrm{dm}^{-3} \mathrm{Mg}$; total exchangeable bases (SB) of $3.73 \mathrm{cmol}_{\mathrm{c}} \mathrm{dm}^{-3}$; cation exchange capacity (CEC) of $6.73 \mathrm{cmol}_{\mathrm{c}} \mathrm{dm}^{-3}$; and base saturation (V) of $55 \%$. Geographic coordinates are latitude $22^{\circ} 32^{\prime} 10 " \mathrm{~S}$, longitude $55^{\circ} 43^{\prime} 32^{\prime \prime} \mathrm{W}$ and altitude of $655 \mathrm{~m}$. According to Köppen, Dourados and Ponta Porã have the climatic classifications of Am (tropical monsoon 
climate) and Cfa (humid temperate climate with hot summer), respectively, as updated by Alvares et al. (2014).

In Dourados, the experimental design was a factorial in complete randomized blocks. Two factors were evaluated. Different plant arrangements that varied in spacing $(20 \mathrm{~cm}, 45 \mathrm{~cm}$, double rows 20 x $60 \mathrm{~cm}$ and crosses at $45 \mathrm{~cm}$ ) and plant populations. For the 2012/2013 season, four plant populations ( $2 / 3$ recommended, recommended, recommended $+1 / 3$ and recommended $+2 / 3$ ) were adopted with cultivars BRS 295RR and BRS 360RR. In the 2013/2014 season, the tested populations were the recommended and recommended $+1 / 3$, with cultivars BRS 295RR and BRS 359RR, while in the 2014/2015 season the recommended and recommended populations $+1 / 2$ were evaluated for cultivars BRS 359RR and BRS 360RR. Recommended populations for BRS 295 RR, BRS 359 RR and BRS 360 RR were 311.108, 311.108 and 355.552, respectively.

The cultivars BRS 295RR, BRS 359RR and BRS 360RR were of determined, indeterminate and indeterminate growth habit, respectively. As for the life cycle, they are classified in relative maturation groups of 6.5, 6.0 and 6.2, respectively.

In Ponta Porã, a randomized block design was adopted with four replicates. The treatments constituted of different spacing $(20 \mathrm{~cm}, 45 \mathrm{~cm}$, double rows $20 \times 60 \mathrm{~cm}$ and crosses at $45 \mathrm{~cm})$. The cultivars BRS 388RR, BRS 1001IPRO and BRS 1010IPRO were tested. In Ponta Porã only the recommended population was used (311.108 plants per hectare for all cultivars). All cultivars show indeterminate growth habit. As for the cycle, the cultivars are classified in an early cycle, with a relative maturity of 6.4, 6.3 and 6.2 for BRS 388RR, BRS 1001IPRO and BRS 1010IPRO, respectively.

The pre-sowing fertilizer application included bulk fertilizer application at the rate of a 450 $\mathrm{kg} \mathrm{ha}^{-1}$ of the NPK 02-20-20 + micro formulation for all experiments, based on soil chemical evaluation. Such a procedure was adopted due to the unavailability of machinery to perform fertilizer application during sowing at reduced spacing and double rows. The plot area was 5 meters wide by 7 meters long.

Sowing was carried out using a Semeato planter model SHM 1517. In the tests with plant populations, seven days after emergence of the seedlings, trimming was performed to remove plants to reach the target population. For sowing seeds in a cross-sowing mode, the sowing machine was adjusted to dispense $50 \%$ of the normal quantity for each direction. The triple sowing experiments at Dourados were carried out on 11/05/2012, 10/28/2013 and 10/28/2014, while in 
Ponta Porã, it was during the 2014/2015 harvest, planting was carried out on 11/10/2014. Precipitation data from Dourados and Ponta Porã during soybean cultivation are presented in Figure 1.
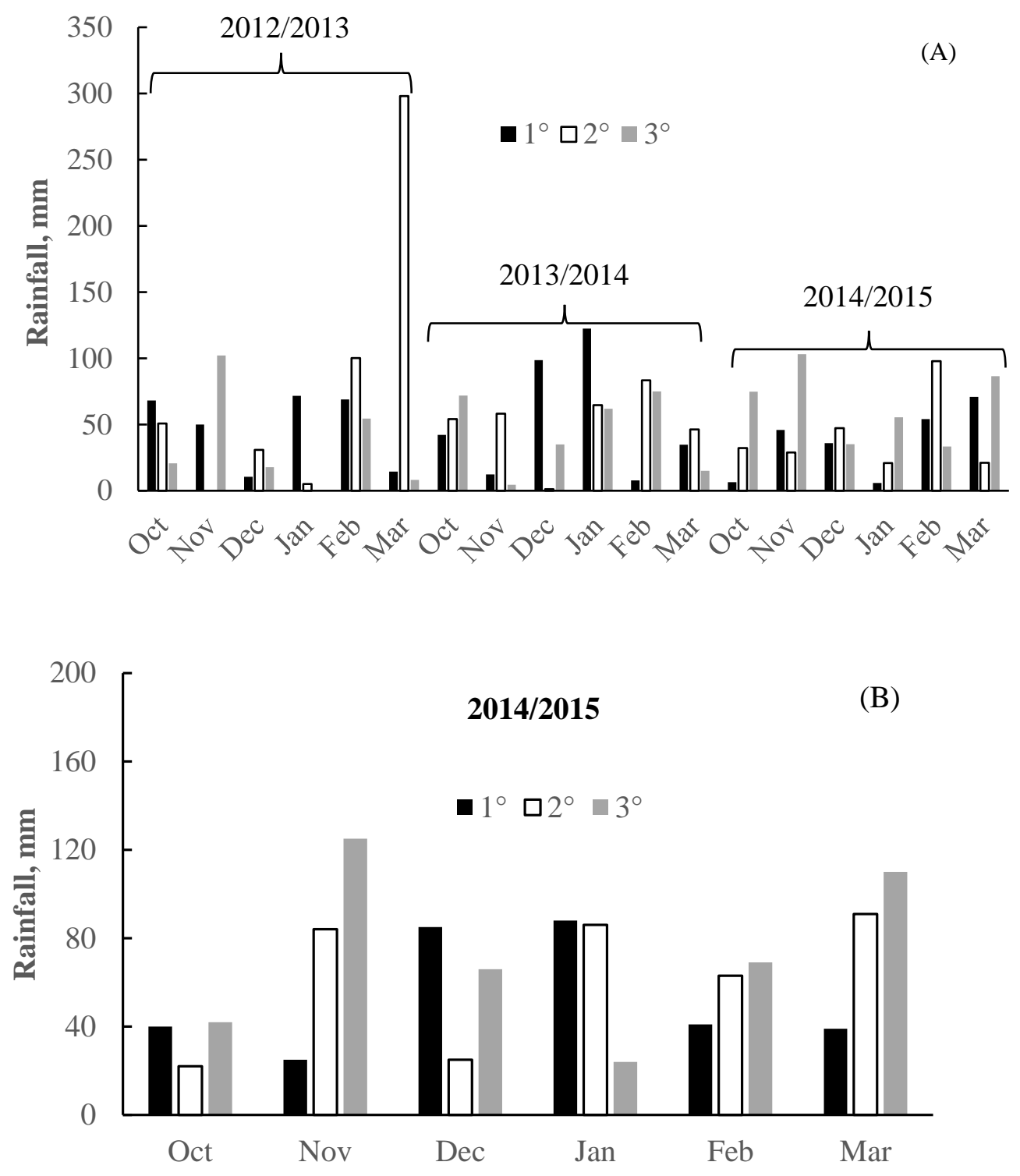

Figure 1. Values of rainfall $\left(1^{\circ}\right.$ : first 10 days period; $2^{\circ}$ : second 10 days period; $3^{\circ}$ : third 10 days period) in Dourados (A) and Ponta Porã (B), Mato Grosso do Sul State, Brazil, obtained from the agrometeorological station of Embrapa Agropecuária Oeste.

The soybean seeds were pre-treated with insecticide and fungicide, as well as inoculated with Bradyrhizobium japonicum. During soybean growing, adequate phytosanitary checks were 
performed according to the recommendations for the soybean crop. It is noteworthy that, even at reduced spacing, there was no significant incidence of Asian Soybean rust, which could have a strong influence on the final outcome.

Harvesting was performed mechanically by harvesting six central rows that were $5 \mathrm{~m}$ long, and excluding the borders. For the cross-sowing method, four subsamples with a $1 \mathrm{~m}^{2}$ template were collected from each experimental unit. Grain productivity was estimated in $\mathrm{kg} \mathrm{ha}^{-1}$, with moisture content adjusted to $13 \%$.

In the crop year 2013/2014, the contribution of the secondary branches in soybean grain yield as a function of plant arrangement was also evaluated for cultivars BRS 359RR and BRS 295RR, with a sample of 15 plants per experimental unit. For the 2014/2015 crop season in Dourados, the number of reproductive branches was determined according to the arrangement of plants, for cultivars BRS 359RR and BRS 360RR.

In the crop year 2012/2013, regression analysis was used to verify the effect of plant population on each spacing tested. The magnitude of the significant regression coefficients by Ftest $(\mathrm{p}<0.05)$ was used as the criterion for choosing the model. For other cases, after analysis using F-test, the means of the treatments were compared by using Tukey test at $5 \%$ probability. The cultivars were always used in the experimental design, but were not compared due to differences in yield potential between these genotypes.

\section{RESULTS AND DISCUSSION}

The analysis of variance, with the probability values from the F-test for the experiments conducted in Dourados, indicated the significant effects of plant population and arrangements, besides the interaction of these factors, on the variable grain yield (Table 1). Regarding the variables related to the architecture of the soybean plants (contribution of the secondary branches in pod yield, and the number of reproductive branches), the positive effects are mainly due to increased population and/or arrangements (Table 2). The experiment conducted in Ponta Porã, MS, in the 2014/2015 season, also shows a significant effect due to arrangement, as evidenced by the F-test (Table 3).

In general, the increase in soybean plant population affected grain yield in both the two cultivars evaluated in the 2012/2013 season (Figure 2). 
Table 1. F test probability and coefficient of variation (C.V) for soybean grain yield as a function of plants arrangements, in the 2012/2013,2013/2014 and 2014/2015 growing seasons, in Dourados, Mato Grosso do Sul State, Brazil.

\begin{tabular}{cccc}
\hline Source of variation & \multicolumn{3}{c}{$2012 / 2013$} \\
\cline { 3 - 4 } & & BRS 295RR & BRS 360 RR \\
\cline { 3 - 4 } Populations (P) & 0.0331 & 0.0071 \\
Arrangements (A) & 0.6210 & 0.1244 \\
PxAS & 0.0413 & 0.0498 \\
C.V (\%) & 14.2 & 16.9 \\
\hline Source of variation & & $2013 / 2014$ & \\
\cline { 3 - 4 } & & BRS 295RR & 0.3313 \\
Populations (P) & 0.1341 & 0.1361 \\
Arrangements (A) & 0.6124 & 0.0247 \\
PxA & 0.0172 & 14.8 \\
C.V (\%) & 18.2 & \\
\hline Source of variation & & BRS 360RR \\
\cline { 3 - 4 } & & BRS 359RR & 0.0947 \\
Populations (P) & 0.0597 & 0.0001 \\
Arrangements (A) & 0.0062 & 0.2891 \\
PxA & 0.4587 & 18.2 \\
C.V (\%) & 14.7 & \\
\hline
\end{tabular}

Table 2. F test probability and coefficient of variation (C.V) for secondary branches contribution to grain yield and number of reproductive branches in the 2013/2014 and 2014/2015 growing seasons, in Dourados, Mato Grosso do Sul State, Brazil.

\begin{tabular}{|c|c|c|}
\hline \multirow[t]{2}{*}{ Source of variation } & \multicolumn{2}{|c|}{ Secondary branches contribution to grain yield - 2013/2014 } \\
\hline & BRS 295RR & BRS 359 RR \\
\hline Populations (P) & 0.0032 & 0.0241 \\
\hline Arrangements (A) & 0.4169 & 0.0001 \\
\hline PxA & 0.0975 & 0.2157 \\
\hline C.V $(\%)$ & 23.21 & 17.99 \\
\hline \multirow[t]{2}{*}{ Source of variation } & \multicolumn{2}{|c|}{ Number of reproductive branches - 2014/2015 } \\
\hline & BRS 359RR & BRS 360RR \\
\hline Populations (P) & 0.0062 & 0.0003 \\
\hline Arrangements (A) & 0.0330 & 0.0494 \\
\hline PxA & 0.9179 & 0.2321 \\
\hline C.V $(\%)$ & 24.23 & 20.66 \\
\hline
\end{tabular}


Table 3. F test probability and coefficient of variation (C.V) for soybean cultivars grain yield as a function of plants arrangements, in the 2014/2015 growing season, in Ponta Porã, Mato Grosso do Sul State, Brazil.

\begin{tabular}{cccc}
\hline Source of variation & BRS 388RR & BRS 1001IPRO & BRS 1010IPRO \\
\hline Arrangements & 0.0552 & 0.0021 & 0.0142 \\
C.V. & 8.99 & 15.08 & 10.22 \\
\hline
\end{tabular}
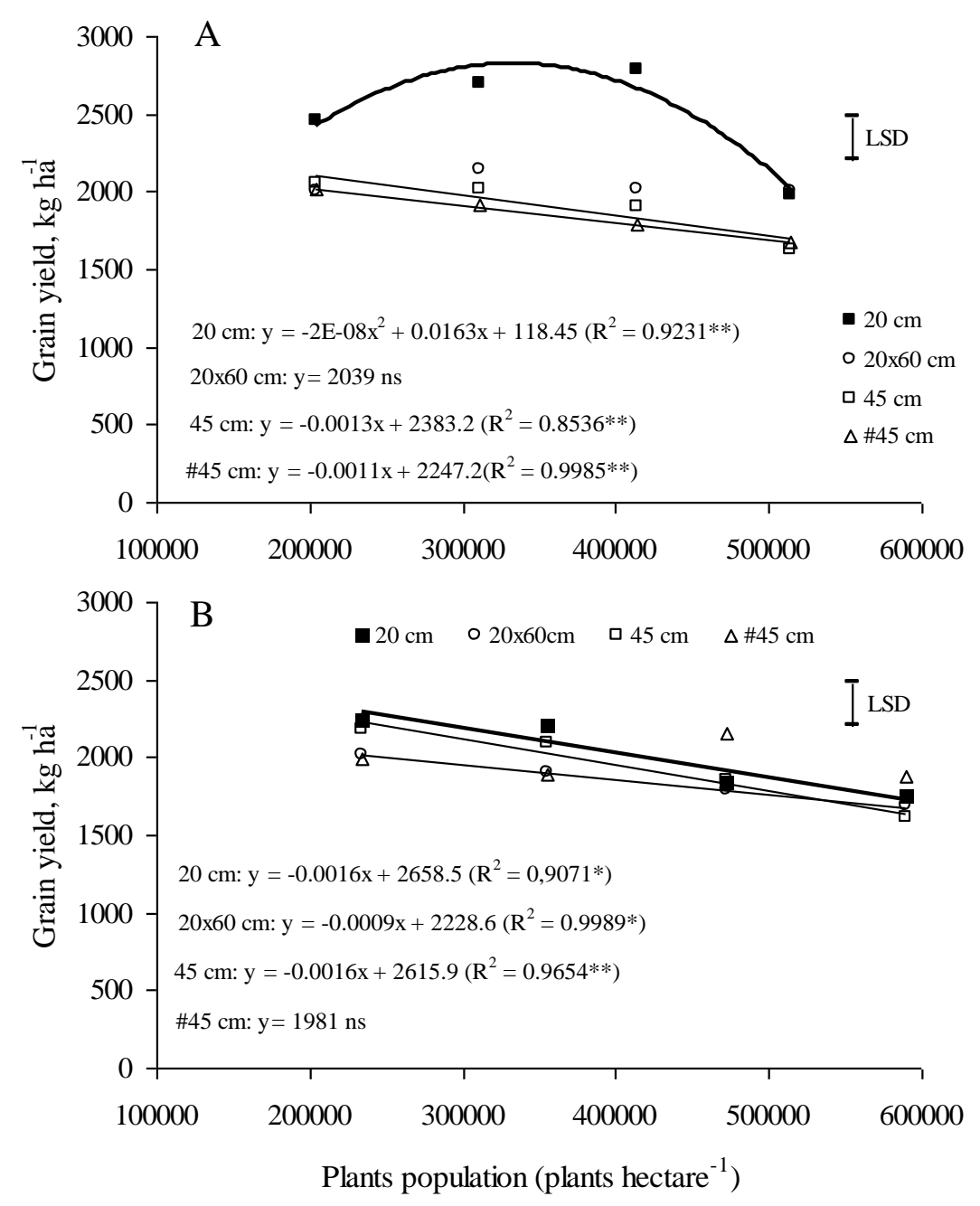

Figure 2. BRS 360RR (A) and BRS 359RR (B) grain yield as affected by plants population and arrangements in the 2012/2013 growing season, in Dourados, Mato Grosso do Sul State, Brazil.

$*$ and **: significant by $5 \%$ and $1 \%$ respectively, according to the $F$-test. LSD: Least significant difference. \#: soybean cross-seeding cultivation using spacing of $45 \mathrm{~cm}$. 
It is also worth noting that the yield was however, low, with maximum values below 3000 $\mathrm{kg} \mathrm{ha}^{-1}$. This can be explained by the low rainfall received during soybean grain filling stage (Figure 1). In this case of low water availability, the increased in plant population affected grain yield because of the competition among plants.

The reduced spacing of $20 \mathrm{~cm}$ provided higher values for the cultivar BRS 360RR up to the recommended population $+1 / 3$ when compared to other arrangements (Figure $2 \mathrm{~A}$ ). For the cultivar with determined growth habit (BRS 295RR), no consistent differences between the spacing was found, although the interaction was significant (Figure 2B and Table 1). The reduced spacing, with better distribution of BRS 360RR plants, may have favored a better development, and decreasing competition among individuals.

In order to reach the maximum yield potential of the plants, it is necessary to have optimal soil conditions and favorable climate, and minimal competition. Studies on new plant arrangements allow for minimizing intraspecific competition and maximizing the use of environmental resources, mainly light energy and water. The modifications in the arrangement can be made by varying the spacing between the plants in the sowing row and the distance between the rows (HEIFFIG et al., 2006). In years with low rainfall, the best plant arrangement and low population may be more favorable.

The 2013/2014 season in Dourados resulted in satisfactory values for grain yield for cultivar BRS 359RR in all treatments, with values around $4000 \mathrm{~kg} \mathrm{ha}^{-1}$ (Figure 3A). For the crosssowing method, with the recommended population, the values were found to be lower. After the emergence and development of the plants, higher competition was observed at the sowing intersections, where there were several more plants. As time progressed, few plants died and some others established and dominated. Spacing with cross-sowing which aimed at a more uniform distribution of plants, was not practical given some operational challenges. Similar trend was observed for cultivar BRS 295RR, with lower values for cross-rows with the recommended population (Figure 3B).

Some studies have reported increase in grain yield with soybean cross-seeding cultivation (SILVA et al., 2015, SOUZA et al., 2016). However, in this study, we did not observe. Moreover, if other aspects are taken into account, such as production costs, operational efficiency and soil compaction, this cultivation technique for soybean is not feasible. For the remaining spacing (20, 45 and $20 \times 60 \mathrm{~cm}$ ), the results were similar, regardless of the cultivars used. 

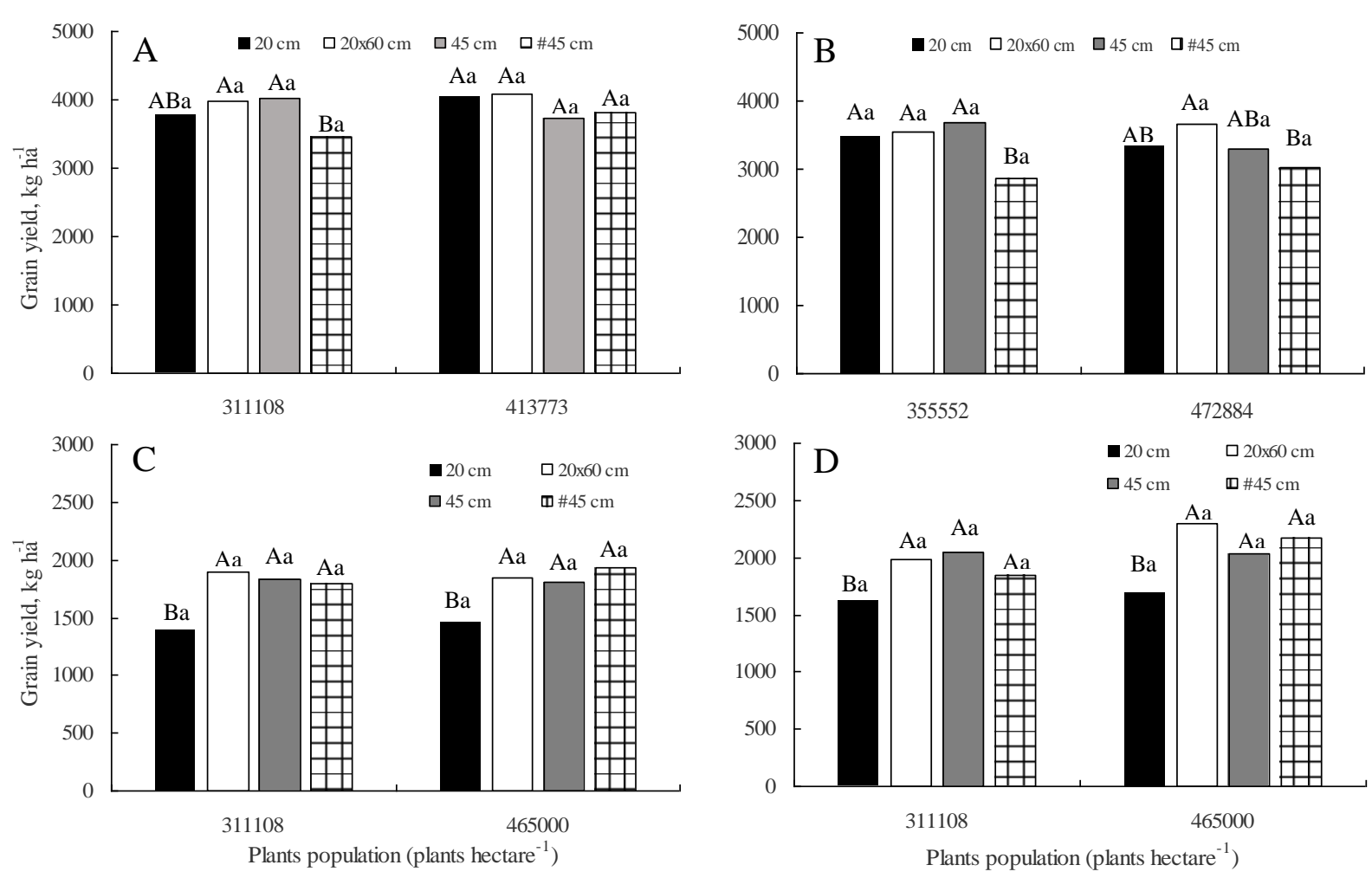

Figure 3. Soybean grain yield as affected by plants arrangements, in Dourados, Mato Grosso do Sul State, Brazil. 2013/2014 for BRS 359RR (A) e BRS 295RR (B) cultivars; 2014/2015 for BRS 359RR (C) e BRS 360RR (D) cultivars.

${ }^{(1)}$ Means followed by the same letter, capital comparing arrangements and small comparing populations, do not differ (Tukey test. $p \leq 0.05$ ). \#: soybean cross-seeding cultivation using spacing of $45 \mathrm{~cm}$.

In the 2013/2014 season in Dourados, it was evident the absence of gains in grain yield due to the increase of the plant population, regardless of the cultivar used (Figures 3A and 3B; Table 1). High population density, besides being costly, also could lead to lodging of the plants, loss of plants and reduced yield. However, low population may encourage weed and result in high losses during harvest (VASQUEZ et al., 2008).

Low yield for the 2014/2015 season was recorded mainly due to the summer incidents during grain filling stage (Figure 1). There were 20 consecutive days without rain; in such a phase the evapotranspiration demand can reach $7 \mathrm{~mm}_{\text {day }}{ }^{-1}$ (BERLATO et al., 1986). In this crop season, the yield obtained for the reduced spacing of $20 \mathrm{~cm}$ were lower for the cultivars BRS 359RR (Figure 3C) and BRS 360RR (Figure 3D). This is in contrast to that observed for reduced spacing in the 2012/2013 season, which was also characterized by water deficiency during the reproductive phase of plants (Figure 1). This can be likely explained by differences in rainfall. The third season 
was characterized by the optimal amount and regularity of rainfall in the early stages of soybean development. It is possible that the root system of the plants was not deep enough in the soil because of the soil moisture in the upper layers. For the reduced spacing, with fewer plants in the row, the roots may have stayed shallow.

There was no effect on plant population during the 2014/2015 season, regardless of the cultivar and spacing used (Table 1; Figures 3C and 3D). In fact, it was expected that the cultivars with indeterminate growth habit, being more compact, would be more tolerant to the increase in plant population, while increasing grain yield. In contrast, this did not occur, and was consistent across all the three agricultural seasons in Dourados. Decrease in the number of pods per plant and/or mass of one thousand grains may occurred. Moreover, for the double row spacing (20 x 60 $\mathrm{cm}$ ), the idea was to have a larger population without compromising light penetration in the plant canopy given the wider corridors $(60 \mathrm{~cm})$. However, this did not in practice improve yield. In the study published by Knebel et al. (2008), the authors emphasize that high plant population negatively affects the productive performance of soybean and plant health more strongly than spacing. The design with reduced spacing with $22.5 \mathrm{~cm}$ was found to be superior to the recommended spacing. Holtz et al. (2014), also evaluated the effect of plant arrangement on the quality of fungicide application, and reported higher productivity with a spacing of $40 \mathrm{~cm}$ between rows than with spacing of 30,60 , and $70 \mathrm{~cm}$.

Soybean yield in the 2014/2015 season in Ponta Porã, was higher when reduced spacing was used (Figure 4). Nevertheless, these positive effects were obtained only for cultivars BRS 1001IPRO and BRS 1010IPRO. For BRS 388RR, changes in row spacing did not improve yield. In the case of BRS 1001IPRO, an intermediate value was obtained for the conventional spacing of $45 \mathrm{~cm}$, being superior to the cross-method and double rows. Due to the growth preferences of Ponta Porã, such as preferred altitude and better rain distribution, the use of appropriate populations and equidistant spacing can be promising, since the creation of plant bedding is favored.

In the four experiments conducted, it can be stated that plant arrangements affected the soybean yield. However, these effects were not consistent, and they were influenced by the cultivar used and climatic conditions. This is a limitation for recommending changes to the conventional spacing model adopted $(45-50 \mathrm{~cm})$. 


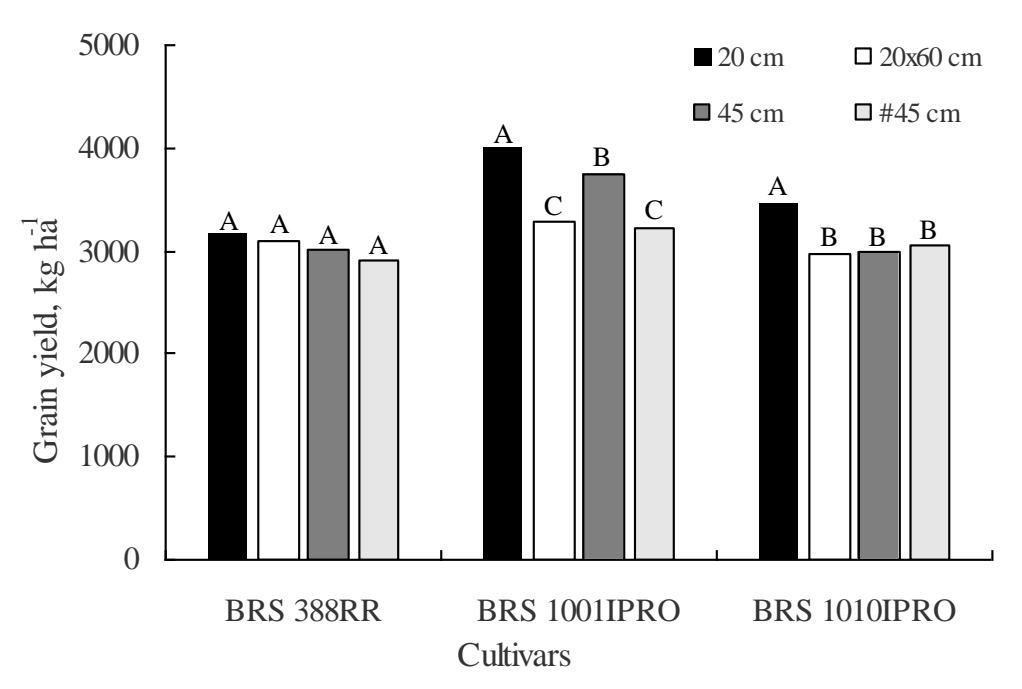

Figure 4. Cultivars grain yield as affected by plants arrangement in the 2014/2015 growing season. Ponta Porã, Mato Grosso do Sul State, Brazil.

${ }^{(1)}$ Means followed by the same letter comparing plants arrangements do not differ (Tukey test. $p \leq 0.05$ ). \#: soybean cross-seeding cultivation using spacing of $45 \mathrm{~cm}$.

The data on contributions of additional branches to soybean yield and numbers of reproductive branches were evaluated in the seasons 2013/2014 and 2014/2015 in Dourados, respectively, as evidenced by the plasticity of the soybean crop (Table 2; Figure 5).

In all the spacing models evaluated, any increase in the population decreased the numbers of branches and minimized contribution of branches to soybean yield. This behavior was seen across all cultivars studied. In addition, in BRS 295RR up to $60 \%$ yield contribution came from the branches (Figure 5B), emphasizing the fact that the selected cultivars had different growth characteristics. However, the cultivars underwent a similar influence due to changes in plant arrangement, either due to change in population or spacing.

In the work of Procópio et al. (2014), the authors highlighted changes in plant architecture as a function of population growth. The number of branches per plant changed from 4.1 to 3.2, while the branch dry matter followed the same trend, decreasing from 13.99 to $11.10 \mathrm{~g} \mathrm{plant}^{-1}$, similar to our results (Figure 5). A large proportion of the phenotypic plasticity of soybean is due to production of branches, which directly competes for available resources but contributes to yield component of pods per plant (PROCÓPIO et al., 2014; BALBINOT JUNIOR et al., 2015b). In a study carried out in Londrina, in the state of Paraná, it was observed that the percentage of pods 
produced in the branches was reduced as spacing decreased, as it probably increased the demand for photosynthesis by the main stem (BALBINOT JUNIOR et al., 2015b).
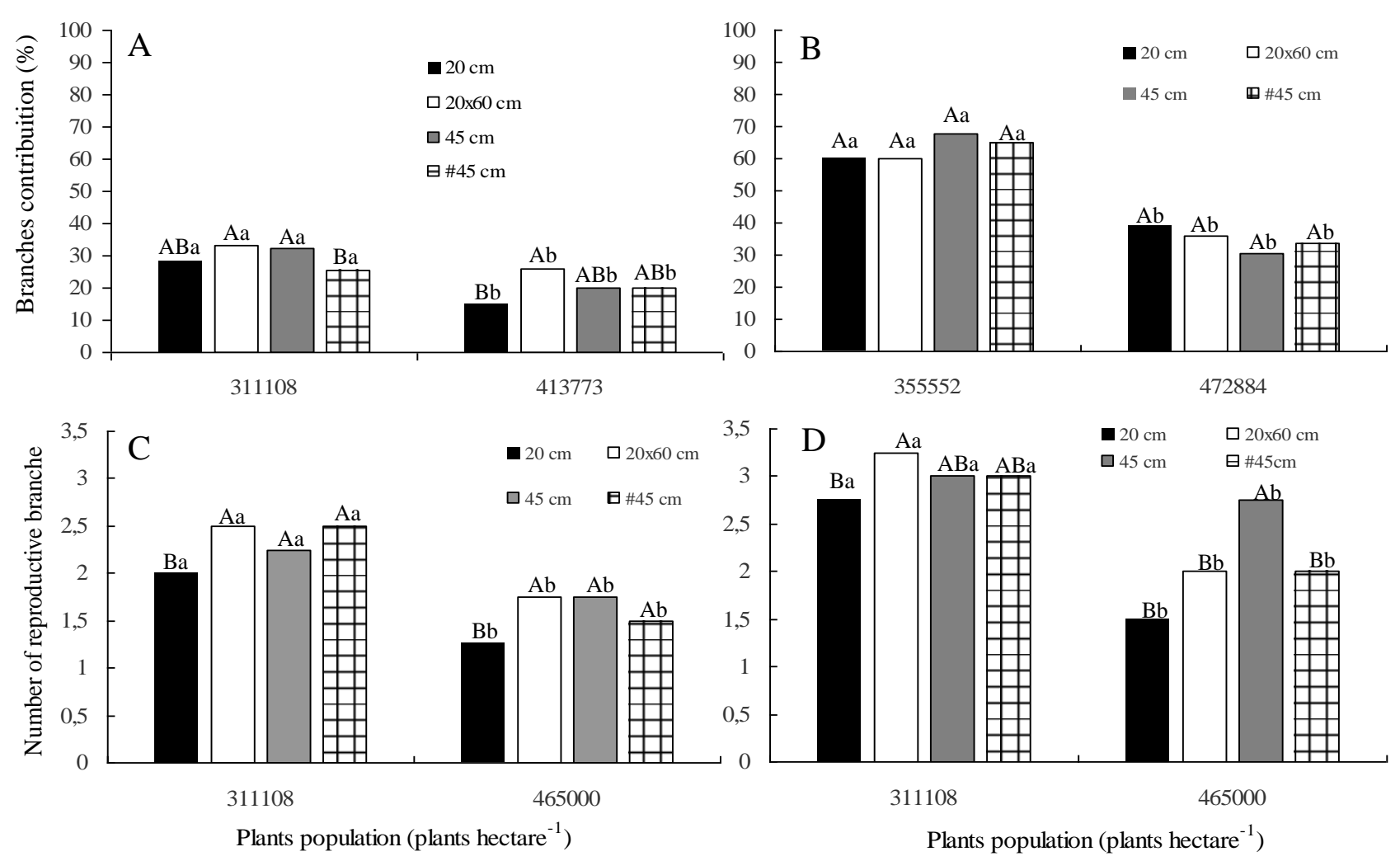

Figure 5. Branches contribution to grain yield as affected by plants arrangements for BRS 359RR (A) e BRS 295RR (B) cultivars, in the 2013/2014 growing season. Number of reproductive branches as a function of plants arrangements for BRS 359RR (A) and BRS 360RR (B) cultivars, in the 2014/2015 growing season. Dourados, Mato Grosso do Sul State, Brazil.

(1) Means followed by the same letter, capital comparing arrangements and small comparing populations, do not differ (Tukey test. $p \leq 0.05$ ). \#: soybean cross-seeding cultivation using spacing of $45 \mathrm{~cm}$.

Marchiori et al. (1999) found that the higher the population of soybean plants in the row, the higher the final plant height, the smaller the diameter of the main stem with fewer branches per plant. According to $\mathrm{Oz}$ (2008), the number of branches per plant decreased with increasing plant population, but grain yield was not affected at densities between 14 and 28 plants $\mathrm{m}^{2}$. The decrease in the number of branches per plant might be related to intraspecific competition, which increased by enhancing the number of plants per area, directly altering the number of branches per plant (SOUZA et al., 2010). Generally, our findings (Figure 5) were in agreement with previous reports. 
For cultivation with indeterminate and compact growth habit (BRS 359RR), it was expected that larger plant populations would be tolerated without impact to the individual production capacity of each plant, which could result in consistent productivity gains. The cultivar BRS 360 $\mathrm{RR}$, although it also has indeterminate growth habit, displays extensive branching than the BRS 359RR, which has been confirmed. However, the changes of these two cultivars as a function of plant arrangement were similar (Figures 5C and 5D). For larger population of plants, production of a small number of lateral branches was observed. Consequently, the concentrated pods on the main stem increase the yield, and this behavior is constant, and independent of the cultivar used. With regard to the spacing, it is emphasized that the reduced spacing results in reduced plant branches. Even with fewer plants in the row, the row spacing decreases considerably, and this might signal the plant to produce fewer lateral branches.

\section{CONCLUSIONS}

The effects of the alternative spacings $(20 \mathrm{~cm}$, double rows $20 \times 60 \mathrm{~cm}$ and crossed to 45 $\mathrm{cm}$ ) in the yield of soybean were punctual, besides being dependent on the cultivar and rainfall that varied in the growing seasons. Therefore, conventional spacing $(45-50 \mathrm{~cm})$ remains the best option for soybean sowing.

The cultivars with indeterminate growth type, although more compact, present considerable plasticity, altering the architecture of the plants due to changes in plant spacing and population.

\section{ACKNOWLEDGEMENTS}

To Fundect (Fundação de Apoio ao Desenvolvimento do Ensino, Ciência e Tecnologia do Estado de Mato Grosso do Sul) for the financial support in part of the project.

\section{REFERENCES}

ALVARES, C.A.; STAPE, J.L.; SENTELHAS, P.C.; GONÇALVES, J.L.M.; SPAROVEK, G. 2014. Koppen's climate classification map for Brazil. Meteorologische Zeitschrift, Stuttgart, v.22, n.6, p. 711-728.

BALBINOT JUNIOR, A.A.; PROCÓPIO, S.O.; DEBIASI, H.; FRANCHINI, J.C.; PANISON, F. 2015a. Semeadura cruzada em cultivares de soja com tipo de crescimento determinado. Semina Ciências Agrárias, Londrina, v.36, n.3, p.1215-1226.

BALBINOT JUNIOR, A.A.; PROCOPIO, S.O.; COSTA, J.M.; KOSINSKI, C.L.; PANISON, F.; DEBIASI, H.; FRANCHINI, J.C. 2015b. Espaçamento reduzido e plantio cruzado associados a 
diferentes densidades de plantas de soja. Semina Ciências Agrárias, Londrina, v.36, n.5, p.2977-2986.

BERLATO, M.A.; MATZENAUER, R.; BERGAMASCHI, H. 1986. Evapotranspiração máxima da soja e relações com a evapotranspiração calculada pela equação de Penman, evaporação do tanque "Classe A" e radiação solar. Agronomia Sulriograndense, Porto Alegre, v.22, n.2, p.243-259, 1986.

BULLOCK, D.; KHAN, S.; RAYBURN, A. 1998. Soybean yield response to narrow rows is largely due to enhanced early growth. Crop Science, Madison, v.38, n.4, p.1011-1016.

EMBRAPA. 2006. Centro Nacional e Pesquisa em Solos. Sistema Brasileiro de Classificação de Solos, Brasilia: Embrapa-SPI; Rio de Janeiro: Embrapa-Solos, 306 p.

FIETZ, C.R.; COMUNELLO, E.; CECCON, G.; FLUMIGNAN, D.; SENTELHAS, P.C. 2013. Risco climático do consórcio milho com braquiária em Mato Grosso do Sul. In: Ceccon, G (ed). Consórcio Milho-Braquiária. Brasília, DF: Embrapa, p.89-112.

HEIFFIG, L.S.; CÂMARA, G.M.S.; MARQUES, L.A.; PEDROSO, D.B.; PIEDADE, S.M.S. 2006. Fechamento e índice de área foliar da cultura da soja em diferentes arranjos espaciais. Bragantia, Campinas, v.65, p.285-295.

HOLTZ, V.; COUTO, R.F.; OLIVEIRA, D.G.; REIS, E.F. 2014. Deposição de calda de pulverização e produtividade da soja cultivada em diferentes arranjos espaciais. Ciência Rural, Santa Maria, v.44, n.8, p. 1371-1376.

KNEBEL, J.L.; GUIMAR ÂES, V.F.; ANDREOTTI, M.; STANGARLIN, J.R. 2008. Influência do espaçamento e população de plantas sobre doenças de final de ciclo e oídio e caracteres agronômicos em soja. Acta Sci. Agron, Maringá, v.28, n. 3, p. 385-392.

MARCHIORI, L.F.S.; CÂMARA, G.M.S.; PEREIRA, C.P.; MARTINS, M.C. 1999. Desempenho vegetativo de cultivares de soja Glycine max (L.) Merrill em épocas normal e safrinha. Scientia Agricola, Piracicaba, v.56, n. 2, p. 383-390.

MARTINS, M. C.; CÂMARA, G. M. S.; PEIXOTO, C. P.; MARCHIORI, L. F. S.; LEONARDO, V.; MATTIAZI, P. 1999. Épocas de semeadura, densidades de plantas e desempenho vegetativo de cultivares de soja. Scientia Agricola, Piracicaba, v.56, n.4, p. 851-858.

OZ, M. 2008. Nitrogen rate and plant population effects on yield and yield components in soybean. African Journal of Biotechnology, Nairobi, v.7, n.24, p.4464-4470.

PEIXOTO, C. P.; CÂMARA, G. M. S.; MARTINS, M. C.; MARCHIORI, L. F. S.; GUERZONI, R. A.; MATTIAZI, P. 2000. Épocas de semeadura e densidade de plantas de soja: 1. Componentes da produção e rendimento de grãos. Scientia Agrícola, Piracicaba, v.57, n.1, p.89-96.

PIRES, J.L.F.; COSTA, J.A.; THOMAS, A.L.; MAEHLER, A.R. 2000. Efeito de populações e espaçamentos sobre o potencial de rendimento da soja durante a ontogenia. Pesquisa Agropecuária Brasileira, Brasília, v.35, n.8, p.1541-1547.

PROCÓPIO, S. O.; BALBINOT JUNIOR, A. A.; DEBIASI, H.; FRANCHINI, J. C.; PANISON, F. 2013. Plantio cruzado na cultura da soja utilizando uma cultivar de hábito de crescimento indeterminado. Revista de Ciências Agrárias/Amazonian Journal of Agricultural and Environmental Sciences, Belém, v.56, n.4, p.319-325.

PROCÓPIO, S.O.; BALBINOT JUNIOR, A.A.; DEBIASI, H.; FRANCHINI, J.C.; PANISON, F. 2014. Semeadura em fileira dupla e espaçamento reduzido na cultura da soja. Revista Agro@mbiente, Boa Vista, v.8, n.2, p. 212-221. 
RAMBO, L.; COSTA, J.A.; PIRES, J.L.F.; PARCIANELLO, G.; FERREIRA, F.G. 2004. Estimativa do potencial de rendimento por estrato do dossel da soja, em diferentes arranjos de plantas. Ciência Rural, Santa Maria, v.34, n.1, p.33-40.

SHAW, R.H.; WEBER, C.R. 1967. Effects of canopy arrangements on light interception and yield of soybeans. Agronomy Journal, Madison, v.59, n.2, p.155-159.

SILVA, P.R.A.; TAVARES, L.A.F.; SOUSA, S.F.G.; CORREIA, T.P.S.; RIQUETTI, N.B. 2015. Rentabilidade na semeadura cruzada da cultura da soja. Revista Brasileira de Engenharia Agrícola e Ambiental, Campina Grande, v.19, n.3, p.293-297.

SOUZA, C.A.; GAVA, F.; CASA, R.T.; BOLZAN, J.M.; KUHNEM JUNIOR, P.R. 2010. Relação entre densidade de plantas e genótipos de soja Roundup ReadyTM. Planta Daninha, Viçosa, v.28, n.4, p.887-896.

SOUZA, R.; TEIXEIRA' I.; REIS, E.; SILVA, A. 2016. Soybean morphophysiology and yield response to seeding systems and plant populations. Chilean journal of agricultural research, Chillán, v.76, p.3-8.

TANAKA, Y.; SHIRAIWA, T. 2009. Stem growth habit affects leaf morphology and gas exchange traits in soybean. Annals of Botany, London, v.104, p.1293-1299.

THOMAS, A. L.; COSTA, J. A.; PIRES, J. L. F. 1998. Rendimento de grãos de soja afetado pelo espaçamento entre linhas e fertilidade do solo. Ciência Rural, Santa Maria, v.28, n.4, p.543546.

VASQUEZ, G. H.; CARVALHO, N. M.; BORBA, M. M. Z. 2008. Redução na população de plantas sobre a produtividade e qualidade fisiológica da semente de soja. Revista Brasileira de Sementes, Londrina, v.30, n.2, p.1-11. 